\title{
EVALUATION OF SALTWATER INTRUSION AND TRAVEL TIME IN THE ATLANTIC CITY 800-FOOT SAND, CAPE MAY COUNTY, NEW JERSEY, 1992, BY USE OF A COUPLED-MODEL APPROACH AND FLOW-PATH ANALYSIS
}

By Lois M. Voronin, Frederick J. Spitz, and Steven D. McAuley

U.S. GEOLOGICAL SURVEY

Water-Resources Investigations Report 95-4280

Prepared in cooperation with the NEW JERSEY DEPARTMENT OF ENVIRONMENTAL PROTECTION 


\title{
U.S. DEPARTMENT OF THE INTERIOR \\ BRUCE BABBITT, Secretary
}

\author{
U. S. GEOLOGICAL SURVEY \\ Gordon P. Eaton, Director
}

For additional information

write to:

\section{District Chief}

U. S. Geological Survey

Mountain View Office Park

810 Bear Tavern Road

Suite 206

West Trenton, NJ 08628
Copies of this report can be purchased from:

U. S. Geological Survey

Earth Science Information Center

Open-File Reports Section

Box 25286, MS 517

Denver Federal Center

Denver, CO 80225-0046 


\section{CONTENTS}

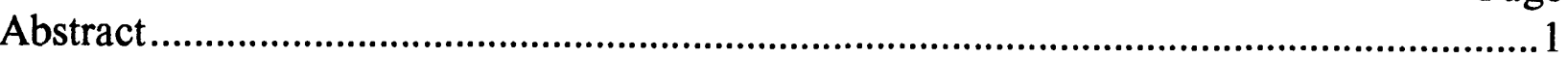

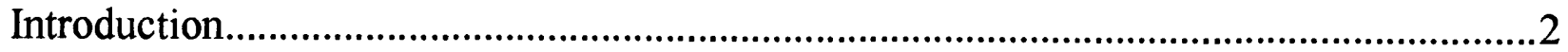

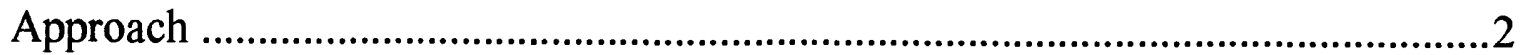

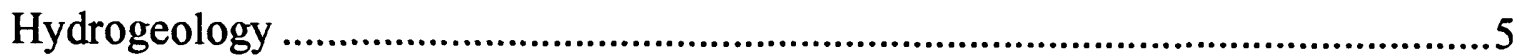

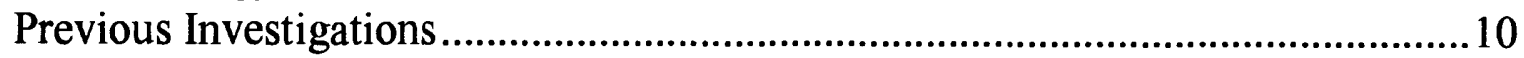

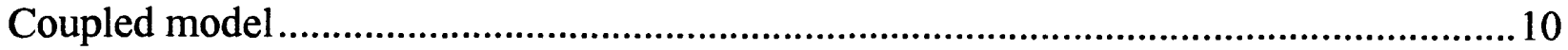

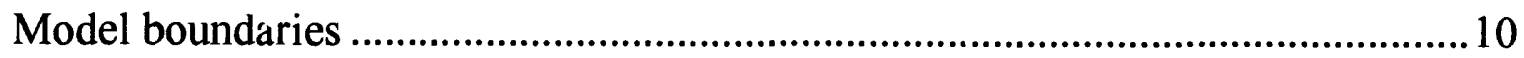

Hydraulic characteristics of aquifer layers and confining unit .............................10

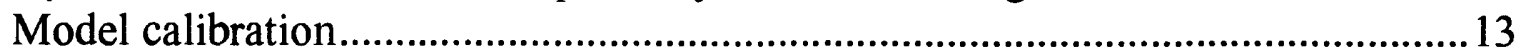

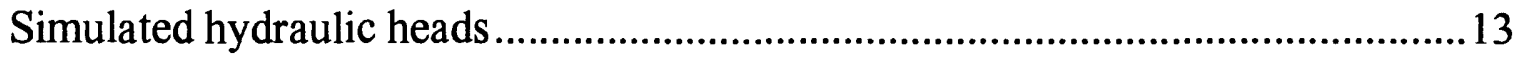

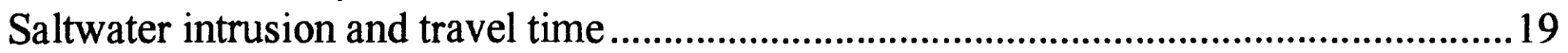

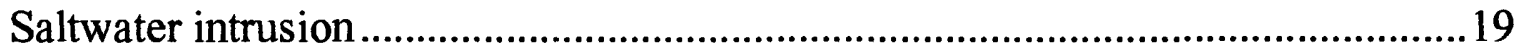

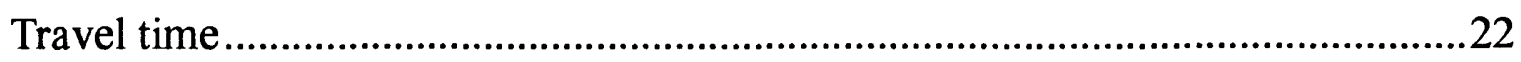

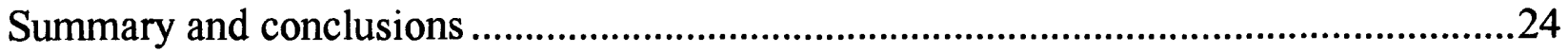

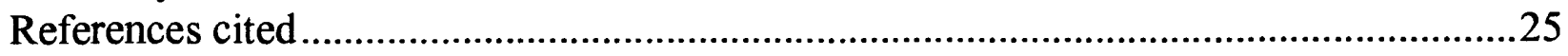

\section{ILLUSTRATIONS}

Figure 1. Map showing location of study area in the New Jersey Coastal Plain ...........3

2. Generalized hydrogeologic section through the Cape May peninsula,

New Jersey, showing the approximate extent of freshwater and saltwater.

3-6. Maps showing:

3. Predevelopment potentiometric surface in the Atlantic City 800 -foot sand in the New Jersey Coastal Plain

4. Potentiometric surface in the Atlantic City 800-foot sand in the New Jersey Coastal Plain, 1988.

5. Subregional model grid and location of model boundaries, Cape May County, New Jersey

6. Location of selected industrial, public supply, and observation wells screened in the Atlantic City 800-foot sand in Cape May and Atlantic Counties, New Jersey....

7. Graphs showing (A) total annual ground-water withdrawals from the Atlantic City 800-foot sand, Cape May County, New Jersey, 1960-91, and (B) water-level hydrograph for well 1-578 


\section{ILLUSTRATIONS--Continued}

Figures 8-11. Maps showing:

Page

8. Simulated potentiometric surface and measured water levels in the upper layer of the Atlantic City 800-foot sand, Cape May County, New Jersey, 1991

9. Simulated potentiometric surface and measured water levels in the lower layer of the Atlantic City 800-foot sand, Cape May County, New Jersey, 1991

10. Estimated location of areas where chloride concentrations exceed 250 milligrams per liter in the Atlantic City 800-foot sand, Cape May County, New Jersey, 1992

11. Flow paths of water particles in the upper layer of the Atlantic City 800-foot sand, Cape May County, New Jersey, determined by particle-tracking analysis of simulation results, 1991

\section{TABLES}

Table 1. Previous investigations of the Atlantic City 800-foot sand, Cape May County, New Jersey 11

2. Well-construction data and average annual withdrawals during 1983-88 for selected wells in Cape May and Atlantic Counties, New Jersey 15

3. Simulated 1983-88 steady-state ground-water budget of the Atlantic City 800-foot sand, Cape May County, New Jersey 


\section{CONVERSION FACTORS, VERTICAL DATUM, AND ABBREVIATED WATER-QUALITY UNITS}

Multiply

foot ( $\mathrm{ft})$

mile (mi)

square foot $\left(\mathrm{ft}^{2}\right)$

square mile $\left(\mathrm{mi}^{2}\right)$

gallon (gal)

gallon (gal)

cubic foot $\left(\mathrm{ft}^{3}\right)$
By

Length

0.3048

1.609

$\underline{\text { Area }}$

0.09294

2.590

Volume

3.785

0.003785

0.02832

Flow

foot per second ( $\mathrm{ft} / \mathrm{s})$

foot per day $(\mathrm{ft} / \mathrm{d})$

cubic foot per second $\left(\mathrm{ft}^{3} / \mathrm{s}\right)$

million gallons per day (Mgal/d)

Hydraulic conductivity

foot per day $(\mathrm{ft} / \mathrm{d})$

0.3048

Transmissivity

square foot per day $\left(\mathrm{ft}^{2} / \mathrm{d}\right)^{1}$
0.3048

0.3048

0.02832

0.04381
0.09290
To obtain

meter

kilometer

square meter

square kilometer

liter

cubic meter

cubic meter

meter per second

meter per day

cubic meter per second

cubic meter per second

square meter per day

Sea level: In this report "sea level" refers to the National Geodetic Vertical Datum of 1929-- a geodetic datum derived from a general adjustment of the first-order level nets of the United States and Canada, formerly called Sea Level Datum of 1929.

Water-quality abbreviations:

$\mathrm{mg} / \mathrm{L}$ - milligrams per liter

1.This unit is used to express transmissivity, the capacity of an aquifer to transmit water. Conceptually transmissivity is cubic feet (of water) per day per square foot ( of aquifer area) times feet (of aquifer thickness), or $\left(\mathrm{ft}^{3} / \mathrm{d}\right) / \mathrm{ft}^{2} \mathrm{x} \mathrm{ft}$. In this report, this expression is reduced to its simplest form, $\mathrm{ft}^{2} / \mathrm{d}$. 


\title{
EVALUATION OF SALTWATER INTRUSION AND TRAVEL TIME IN THE ATLANTIC CITY 800-FOOT SAND, CAPE MAY COUNTY, NEW JERSEY, 1992, BY USE OF A COUPLED-MODEL APPROACH AND FLOW-PATH ANALYSIS
}

\author{
By Lois M. Voronin, Frederick J. Spitz, and Steven D. McAuley
}

\section{ABSTRACT}

Regional and subregional ground-water-flow models were coupled, and the output was analyzed by a particle-tracking method. The results were then used to assess the effects of ground-water withdrawals on the flow of saltwater in the Atlantic City 800-foot sand in Cape May County, New Jersey, and to estimate the travel time from areas in which the chloride concentration of the ground water exceeds 250 milligrams per liter to the county's nearest public supply wells.

First, a quasi-three-dimensional finite-difference computer model of freshwater and saltwater flow that simulated regional ground-water flow through the unconsolidated materials underlying the New Jersey Coastal Plain was used to estimate flow at the boundaries of the subregional study area. The results of the regional simulation were used as input to a second quasi-three-dimensional finite-difference model that was used to simulate flow in the subregion, the Atlantic City 800-foot sand in Cape May County.

The results of the simulation of flow in the subregion were analyzed by a semianalytical particle-tracking method to estimate ground-water flow paths and travel time of ground water from areas in which chloride concentrations exceed 250 milligrams per liter to public supply wells located at Stone Harbor, New Jersey. Ground-water withdrawals from the Atlantic City 800 -foot sand were assumed to be equal to those reported for 1991. Results of the analysis indicate that the time required for saltwater to reach the public supply wells is on the order of hundreds of years. These results, however, are based on the assumptions that the aquifer is homogeneous. The presence of zones of high permeability in the aquifer could reduce the predicted travel times of the saltwater from its present location to the supply wells. Travel times also could be reduced if ground-water withdrawals increase. 


\section{INTRODUCTION}

Ground water is the most important source of public water supply in Cape May County, New Jersey (fig. 1). In the barrier-island communities, ground water is withdrawn from the regionally confined aquifer system, the Atlantic City 800 -foot sand. Additional supplies are obtained and transported from the shallow ground-water system on the mainland. The presence of saline ground water (ground water in which the chloride concentration exceeds $250 \mathrm{mg} / \mathrm{L}$ ) in Cape May County was documented in 1926 when water samples from a well screened in the Atlantic City 800-foot sand in Wildwood (fig. 1) were found to contain chloride in a concentration of $352 \mathrm{mg} / \mathrm{L}$ (Gill, 1962a, table 7).

Water from a well sampled in 1957 in Cape May City contained chloride in a concentration of $1,510 \mathrm{mg} / \mathrm{L}$ (Gill, 1962, table 7) and confirmed the presence of saltwater in Cape May County. These data indicate that saltwater intrusion in the Atlantic City 800foot sand had occurred prior to 1926, possibly as a result of the presence of a large zone of diffusion that broadened in response to sea-level fluctuations during the Pleistocene glacial periods (Meisler and others, 1985). The saltwater may be moving landward in response to ground-water withdrawals and (or) because the system is not in equilibrium as a result of these fluctuations.

Concern about the future adequacy of freshwater supplies from the Atlantic City 800 -foot sand in Cape May County led the U.S. Geological Survey, in cooperation with the New Jersey Department of Environmental Protection, to undertake a study of saltwater intrusion in this aquifer in order to estimate the travel time of the saltwater from its present location to the public supply wells at Stone Harbor in Cape May County, New Jersey. This report presents the results of the study and describes the calibrated ground-waterflow model and the particle-tracking technique that were used to estimate travel time.

\section{Approach}

A regional and a subregional ground-water-flow model were coupled to assess the effects of ground-water withdrawals on the flow of saltwater in the Atlantic City 800-foot sand. Model coupling has been shown to be a useful approach to ground-water-flow simulation by Buxton and Reilly (1986). First, a regional model of ground-water-flow through the sediments of the New Jersey Coastal Plain (D.A. Pope, U.S. Geological Survey, written commun., 1991) was used to estimate the quantity and distribution of flow across the natural and artificial boundaries of the Cape May subregional model area. Next, the results of this simulation were input to the subregional model to refine the estimates of flow in the Atlantic City 800 -foot sand in the smaller area of interest. Finally, a particle-tracking method was used to estimate ground-water-flow paths and travel time from parts of the aquifer that contain saltwater to the public supply wells at Stone Harbor, New Jersey (fig. 1). 


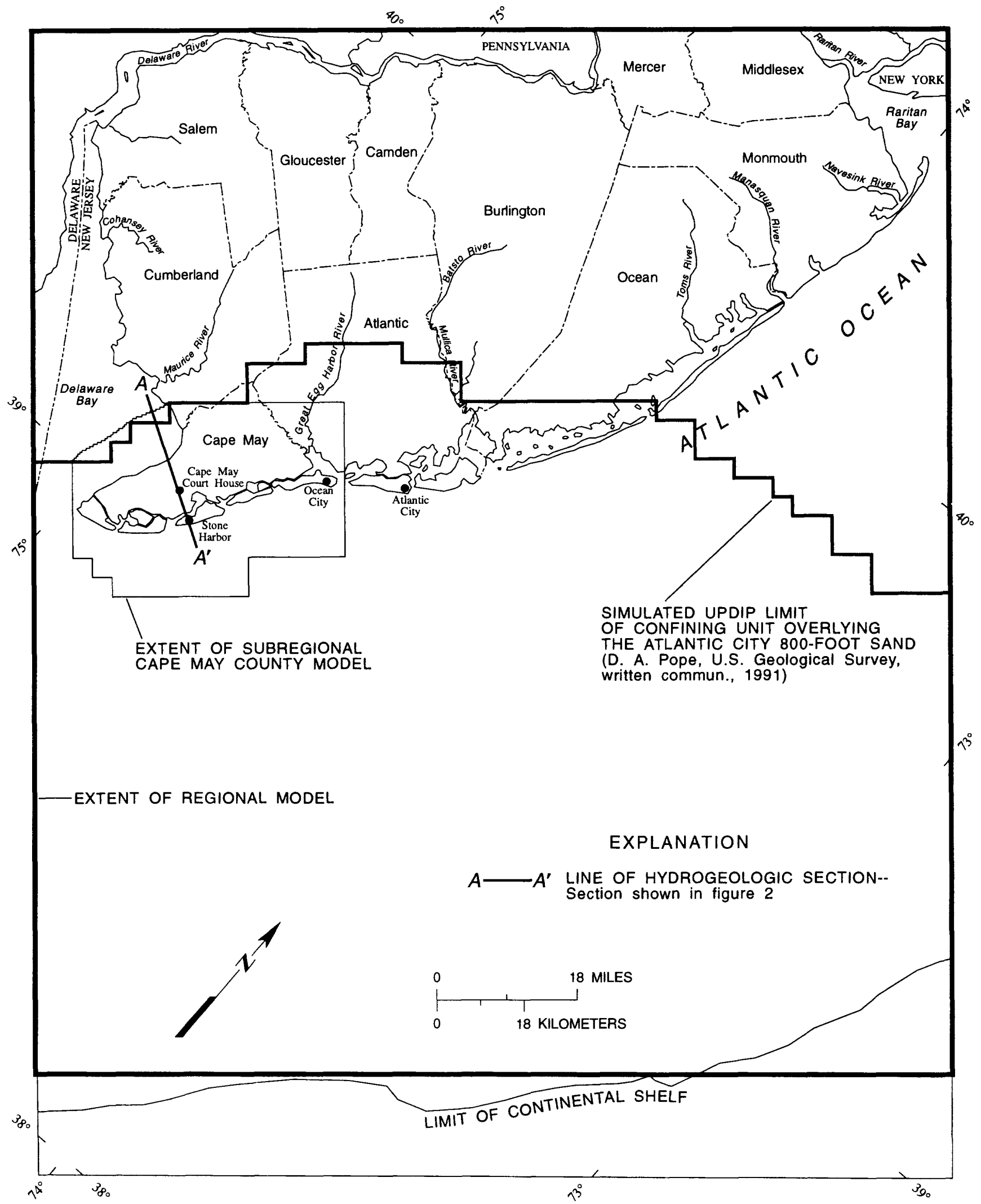

Base from U.S. Geological Survey digital data, 1:2,000,000, 1972

Universal Transverse Mercator projection, Zone 18

Figure 1. Location of study area in the New Jersey Coastal Plain. 
The regional model extends to the natural boundaries of the Coastal Plain sediments at the outcrop to the northwest and the subcrop to the southeast, at the continental shelf (fig. 1). Its northeast and southwest boundaries are artificial boundaries in offshore areas where flows were calculated with a model of the Northern Atlantic Coastal Plain (Leahy and Martin, 1993). The regional model is coarsely discretized, with a grid-cell size of $13,200 \mathrm{ft}$ on each side in the subregional model area. Ground-water flow in the regional model area was simulated by use of SHARP (Essaid, 1990), a quasi-threedimensional finite-difference computer model of freshwater and saltwater flow separated by a sharp interface in a layered coastal aquifer system.

Results of the simulation with the SHARP model were used in the subregional model as simulated ground-water flow at the boundaries of the subregional model area. Ground-water flow in the Atlantic City 800-foot sand in the subregional model area (fig. 1) was simulated by the use of MODFLOW (McDonald and Harbaugh, 1988). The subregional model is more finely discretized than the regional New Jersey Coastal Plain model. The cell size in the subregional Cape May County model grid, 1,320 ft on each side, allows for a sufficiently detailed representation of local variations in thickness, water levels, and distribution of ground-water withdrawals to estimate travel time of saltwater moving toward public supply wells.

The regional model was used to simulate ground-water flow and movement of the freshwater-saltwater interface $(10,000 \mathrm{mg} / \mathrm{L}$ chloride concentration), including the quantity and distribution of flow across the interface and accounted for density differences between freshwater and saltwater. The boundaries of the subregional model do not extend to the freshwater-saltwater interface in the Atlantic City 800-foot sand, but are located 9 mi or more from it. Therefore, the use of MODFLOW to simulate fresh ground-water flow in the Atlantic City 800-foot sand in Cape May County is valid.

Ground-water-flow paths and travel time from parts of the aquifer that contain saltwater to the public supply wells at Stone Harbor, New Jersey, were estimated by use of a semianalytical particle-tracking method. The method is used to calculate steady-state flow paths in a block-centered finite-difference ground-water-flow model. The interblock flows calculated with the subregional steady-state model were used as input to the particle-tracking method. The method incorporates the assumption that the velocity in each coordinate direction varies linearly between the velocities calculated by the flow model at each face of the finite-difference block. Under these conditions, an analytical expression is derived that describes the three-dimensional velocity field within each block. After the three-dimensional velocity distribution is calculated for each block in the flow model, the unique path of any particle within the model area can be determined. The mathematical derivation of and analytical expressions for the particle-tracking algorithm are given in Pollock (1989). 
Flow paths calculated by the particle-tracking method are based on average linear velocities computed by the finite-difference model. Hydrodynamic dispersion (mixing or spreading) of a chemical species as a result of small-scale velocity variations is not considered. Although flow paths calculated with this method are accurate for the model representation of the ground-water-flow system, any numerical model is a simplification of the actual ground-water-flow system that can cause results to be inaccurate (Pollock, 1989).

\section{Hydrogeology}

The Atlantic City 800-foot sand is located in New Jersey in the Coastal Plain Physiographic Province. The Coastal Plain sediments consist of layers of gravel, sand, silt, and clay that gently dip and thicken to the southeast. The Atlantic City 800 -foot sand lies within the lower part of the Kirkwood Formation of middle Miocene age and is a regionally confined aquifer system (fig. 2) that is bounded above and below by thick confining units that attain maximum thicknesses of 200 and $140 \mathrm{ft}$, respectively (P.J. Lacombe and G.B. Carleton, U.S. Geological Survey, written commum., 1992). In Cape May County, the Holly Beach water-bearing zone, estuarine sand aquifer, Cohansey aquifer, and Rio Grande water-bearing zone overlie the Atlantic City 800-foot sand. The Piney Point aquifer, Wenonah-Mount Laurel aquifer, and Potomac-Raritan-Magothy aquifer system underlie it; these aquifers do not provide potable water for Cape May County and, therefore, are not discussed in detail in this report.

The confining unit overlying the Atlantic City 800 -foot sand is described by Martin (in press), D.A. Pope (U.S. Geological Survey, written commun., 1991) and P.J. Lacombe (U.S. Geological Survey, written commun., 1992). For this study, the limit of this overlying confining unit is the same as that assumed by D.A. Pope (U.S. Geological Survey, written commun., 1991) for the New Jersey Coastal Plain regional model. The updip limit of the confining unit that overlies the Atlantic City 800-foot sand is west and north of Cape May County in Ocean, Burlington, Atlantic, and Cumberland Counties (fig. 1). In these areas, the Atlantic City 800-foot sand is in direct hydraulic connection with the overlying Kirkwood-Cohansey aquifer system. In areas where the confining unit overlying the Atlantic City 800- foot sand is truncated in the Delaware Bay or the Atlantic Ocean, offshore from Ocean County, the saltwater is hydraulically connected to the freshwater in the Atlantic City 800-foot sand (fig. 2). Directly to the east, the overlying confining unit is assumed to extend to the continental shelf (fig. 1) (D.A. Pope, U.S. Geological Survey, written commun., 1991). 


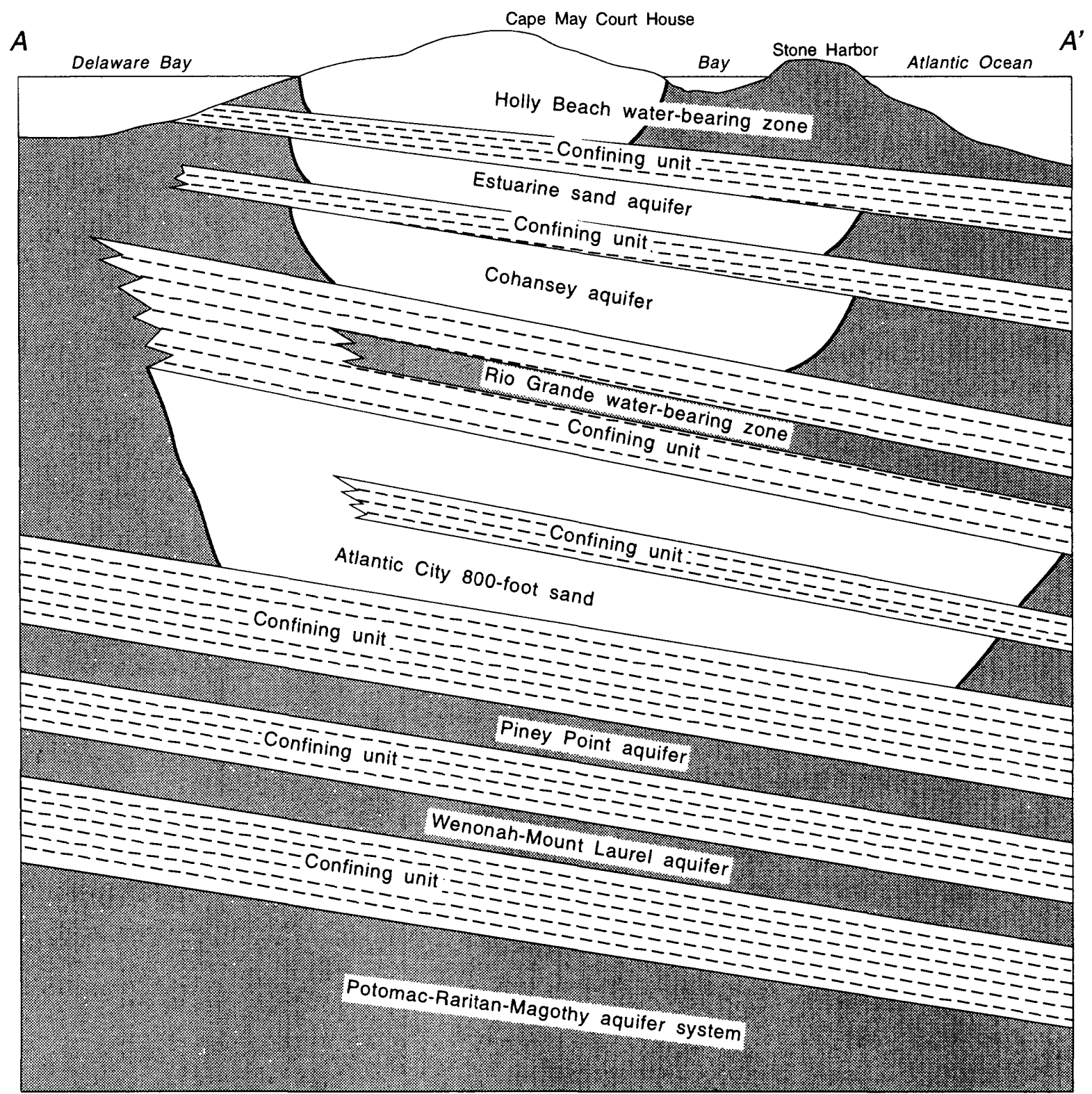

NOT TO SCALE

\section{EXPLANATION}

Saltwater

Freshwater

Approximate location of saltwater-

freshwater interface

Figure 2. Generalized hydrogeologic section through the Cape May peninsula, New Jersey, showing the approximate extent of freshwater and saltwater. (Location of section shown in fig. 1) 


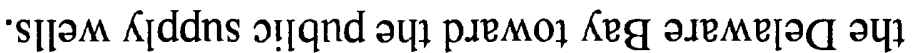

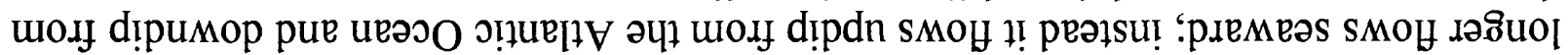

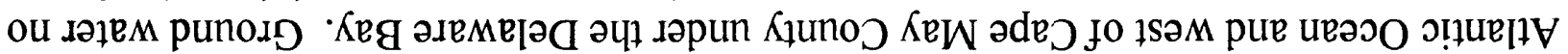

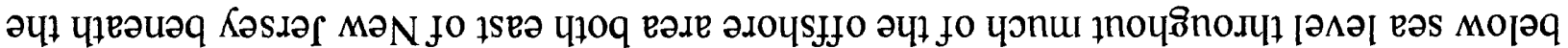

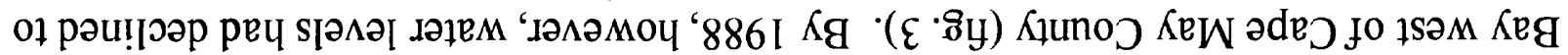

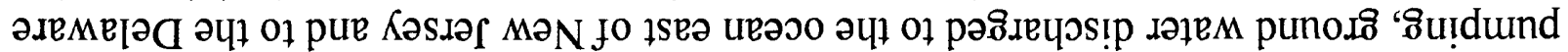

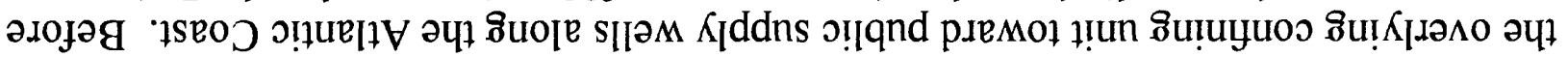

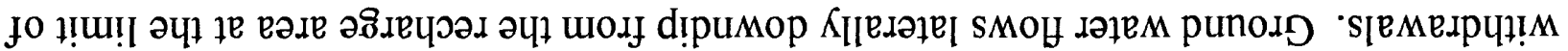

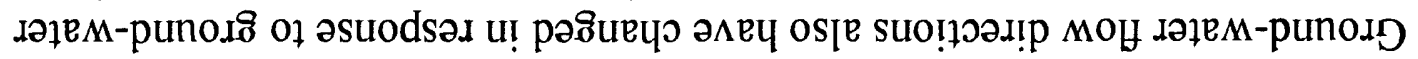

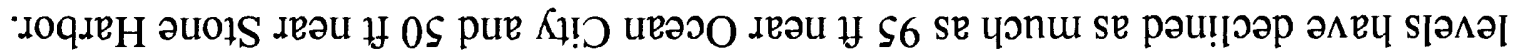

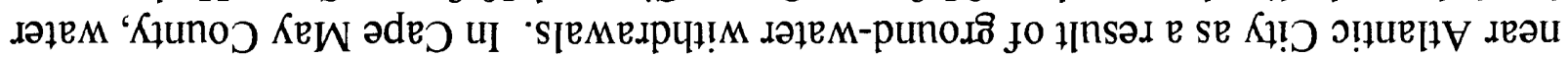

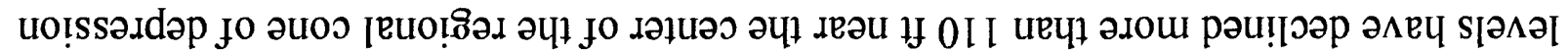

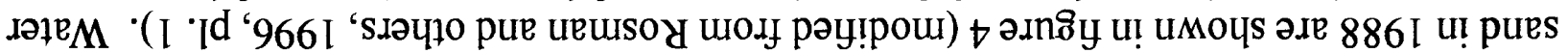

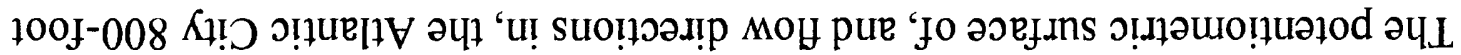

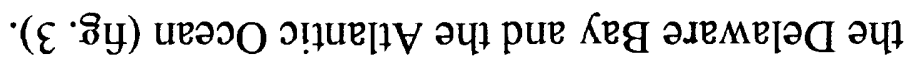

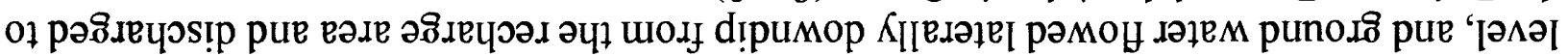

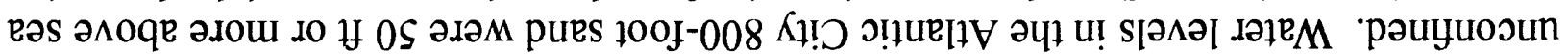
S! גәј!nbe әцा әдәчм 'ұ!

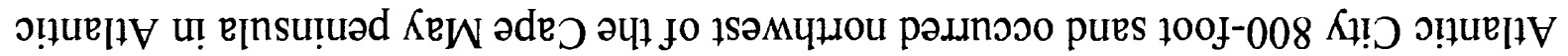

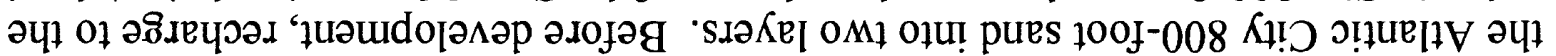

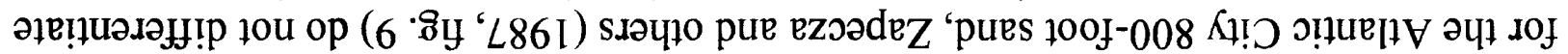

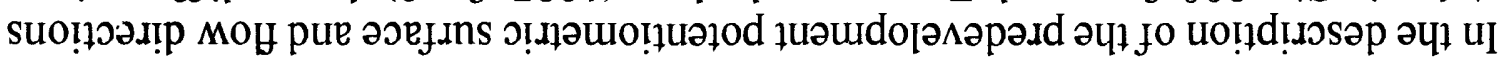

$\forall 0 \varepsilon I$

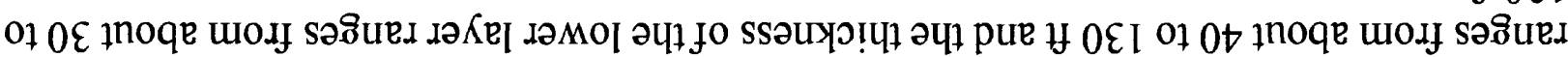

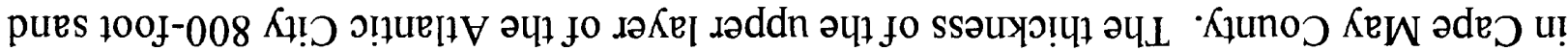

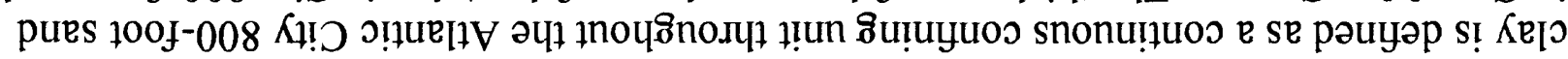

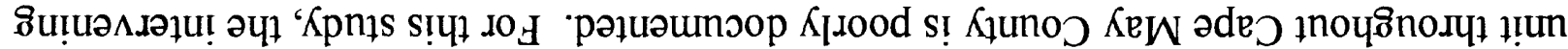

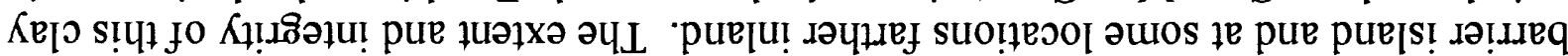

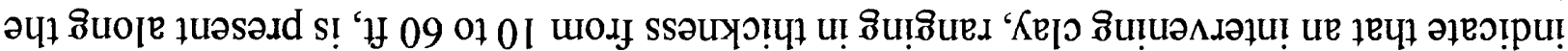

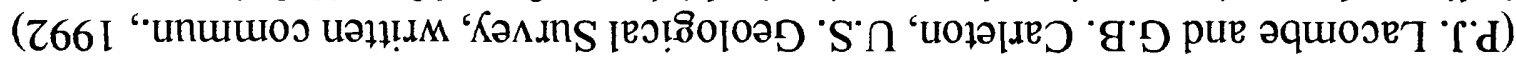

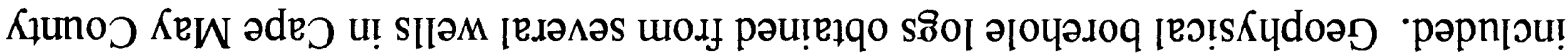

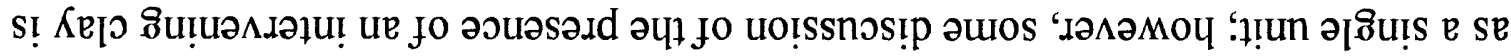

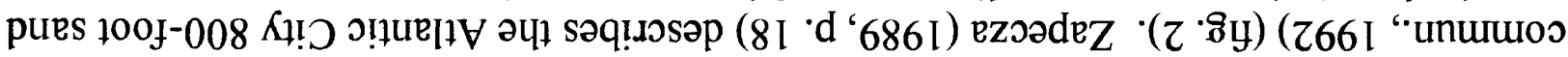

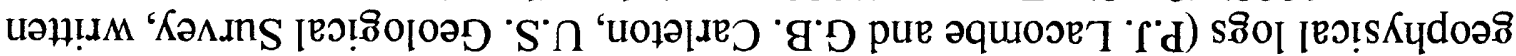

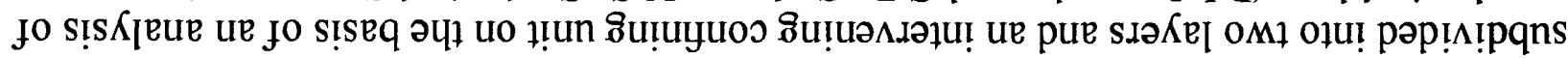

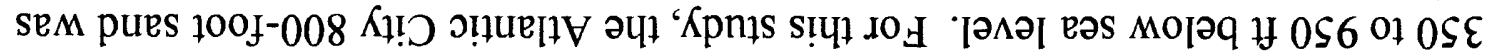

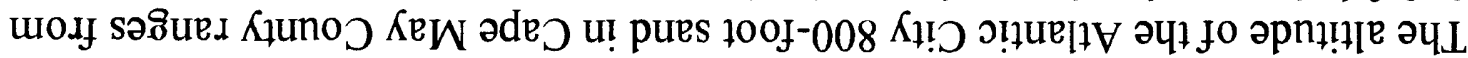




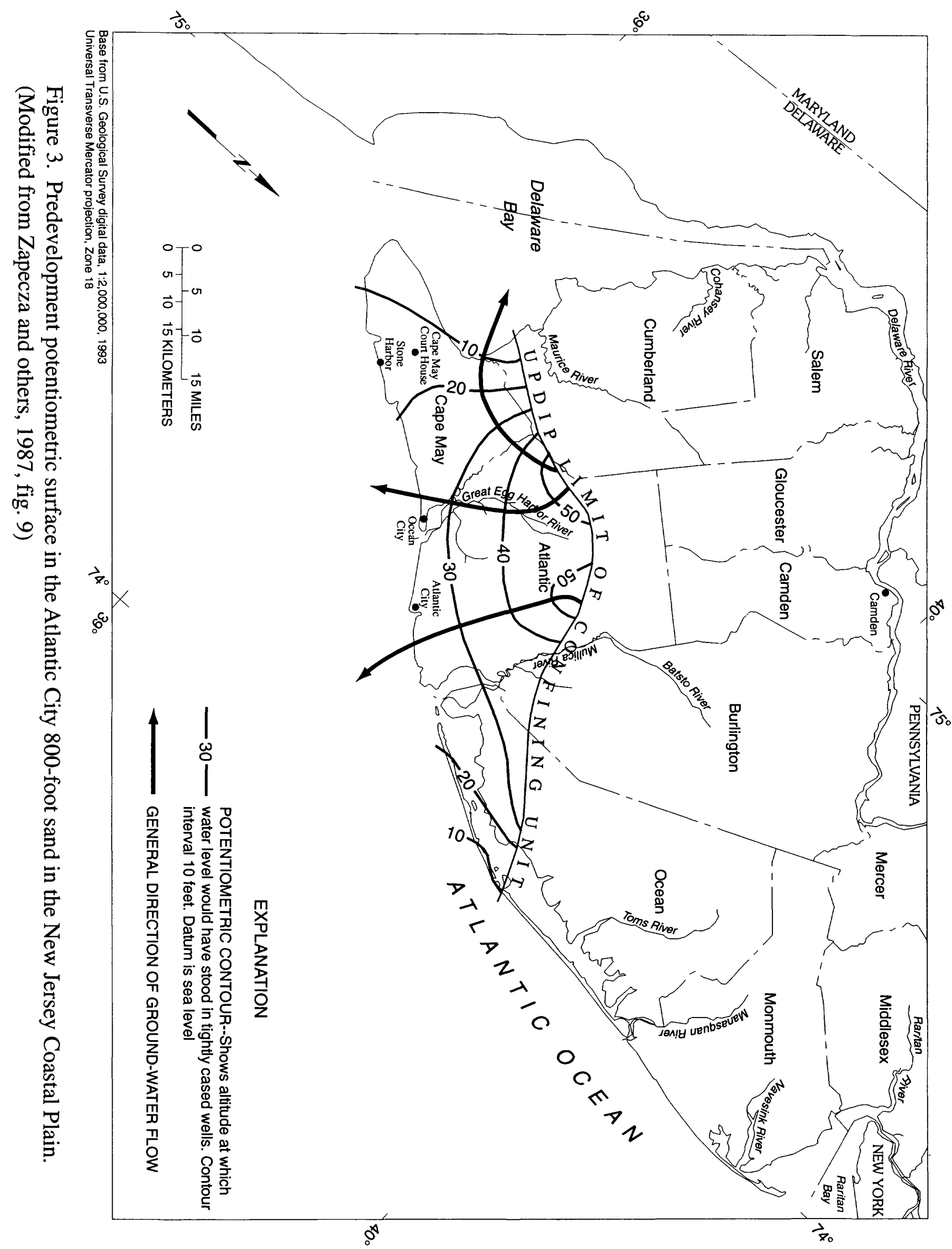




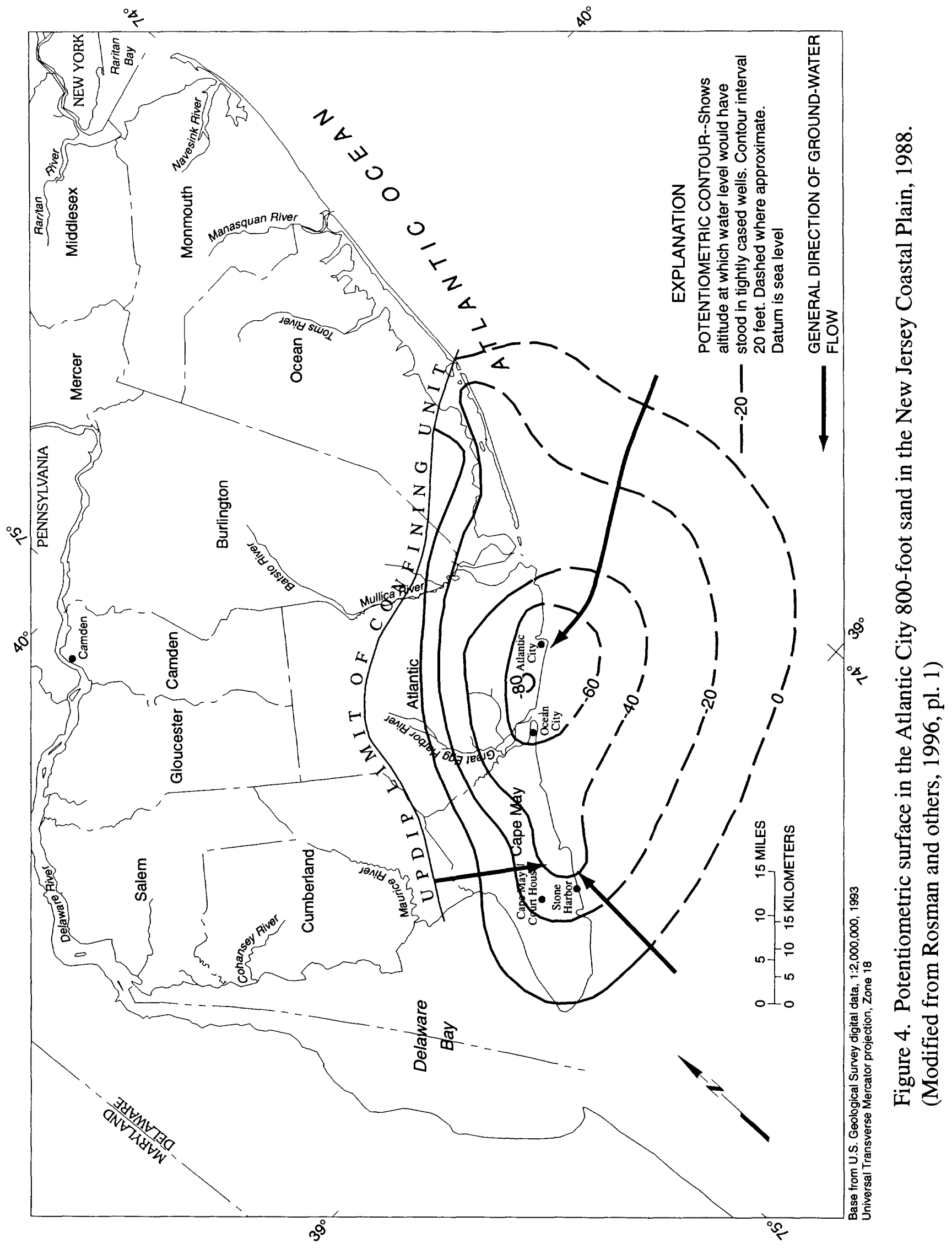




\section{Previous Investigations}

Several studies of the ground-water resources of Cape May County, New Jersey, have been conducted. These studies also evaluated the hydrogeology of, aquifer and confining-unit properties of, and water levels and chloride concentrations in Cape May County's aquifer system. Studies that include the Atlantic City 800 -foot sand are summarized in table 1, where they are divided into three categories: (1) countywide studies, (2) Coastal Plain studies, and (3) simulation studies.

\section{COUPLED MODEL}

The subregional model was used to simulate ground-water flow in the two aquifer layers and the intervening confining unit of the Atlantic City 800- foot sand. The model consists of a finite-difference grid with 100 rows and 140 columns. Each cell is $1,320 \mathrm{ft}$ on a side.

\section{Model Boundaries}

The boundaries of the subregional model are shown in figure 5. The top and bottom boundaries were represented as specified fluxes across confining units. The lateral boundaries were assigned specified ground-water fluxes, except at the limit of the confining unit overlying the Atlantic City 800 - foot sand under the Delaware Bay, where the sediments are unconfined (fig. 2). At this location, a head-dependent boundary was used (fig. 5). All specified fluxes were applied as ground water that flows from the regional model into or out of the Cape May County subregional model area. At the lateral boundaries of the subregion, the specified flows from the regional model were apportioned according to the relative thickness of the two aquifer layers in the subregional model.

For the head-dependent boundary under the Delaware Bay, the water level and vertical conductance were specified. A water level of zero, which represents the water level in the Delaware Bay, and a vertical conductance of $0.001 \mathrm{ft} / \mathrm{d}$, which represents the product of the hydraulic conductivity of the sediments and the area of the model cell divided by the thickness of the sediments, were assigned to model nodes.

\section{Hydraulic Characteristics of Aquifer Lavers and Confining Unit}

Few values of hydraulic conductivity have been reported for the Atlantic City 800foot sand in Cape May County. Gill (1962, p. 47) reports a horizontal hydraulic conductivity for the Atlantic City 800 -foot sand of 38 to $41 \mathrm{ft} / \mathrm{d}$ in the Stone Harbor area. Horizontal hydraulic conductivities used in the model were $35 \mathrm{ft} / \mathrm{d}$ for the upper layer of the Atlantic City 800 - foot sand and $55 \mathrm{ft} / \mathrm{d}$ for the lower layer. A vertical hydraulic 
Table 1. Previous investigations of the Atlantic City 800 -foot sand, Cape May County, New Jersey (Modified from Spitz and Barringer, 1992, table 1.)

\begin{tabular}{ll}
\hline Reference & Area or subject \\
\hline \hline
\end{tabular}

\section{COUNTYWIDE STUDIES}

Geraghty and Miler, 1971

Gill, 1962a

Gill, 1962b
Gound-water resources

Ground-water resources, saltwater intrusion

Well records and logs, stratigraphy

\section{COASTAL PLAIN STUDIES}

Bauersfeld and others, 1990

Eckel and Walker, 1986

Meisler, 1980

Rosman and others, 1996

Seaber, 1963

Schaefer, 1983

Vowinkel, 1984

Vowinkel and Foster, 1981

Walker, 1983

Zapecza, 1989

Zapecza and others, 1987
Water-resources data

Aquifer water levels, 1983

Delineation of salty ground water

Aquifer water levels, 1988

Chloride concentrations, 1923-61

Chloride concentrations, 1977-81

Ground-water withdrawals, 1956-80

Hydrogeologic conditions

Aquifer water levels, 1978

Hydrogeologic framework

Predevelopment aquifer water levels, withdrawals

\section{SIMULATION STUDIES}

Martin, in press

Meisler and others, 1985
Ground-water flow, Coastal Plain

Sea-level effects on saltwater-freshwater relations, Coastal Plain 
conductivity of $0.001 \mathrm{ft} / \mathrm{d}$ was assigned to the confining unit between the two layers. Leakance between the two aquifer layers was simulated by dividing this value by the thickness of the confining unit, which ranged from 10 to $60 \mathrm{ft}$.

\section{Model Calibration}

The subregional model was calibrated to water levels measured during April 1991 in 33 wells ( 6 observation wells and 27 public and industrial supply wells) screened in the Atlantic City 800-foot sand in Cape May and Atlantic Counties (fig. 6). Although the model was used to simulate steady-state conditions and water levels in April 1991 were higher than average, this was the most recent and complete data set available.

The model was calibrated by using average annual ground-water withdrawals during 1983-88. Well-construction data and average ground-water withdrawals during 1983-88 for the public supply and observation wells are listed in table 2 .

The long-term hydrograph for well 1-578, shown in figure 7 along with annual rates of ground-water withdrawals from public supply wells in Cape May County, indicates that water levels declined during 1960-91 as a result of increasing ground-water withdrawals. As ground-water- withdrawal rates increased during 1960-87, water levels declined. After 1987, water levels in well 1-578 began to level off, probably because ground-water-withdrawal rates did not increase. The ground-water system may have reached equilibrium with 1987-90 withdrawal rates. Ground-water withdrawals throughout much of the Atlantic City 800 -foot sand are near coastal areas and are seasonal. Water use in the coastal areas of southern New Jersey is greatly affected by the summer resort industry; ground-water withdrawals are much greater during May through September than during October through April. The highest water levels of the year consistently are measured in April. The annual average water levels during 1983-90 are about $10 \mathrm{ft}$ lower than the water level measured in April 1991. The model, therefore, was considered to most closely approximate steady-state conditions when simulated water levels were about $10 \mathrm{ft}$ lower than April 1991 water levels.

\section{Simulated Hydraulic Heads}

The simulated potentiometric surface and water levels measured in April 1991 in the two layers of the Atlantic City 800 -foot sand are shown in figures 8 and 9 . In general, the simulated water levels are slightly less than $10 \mathrm{ft}$ lower than the water levels measured in April 1991. The simulated water level in observation well 9-185 (April 1991 water level $29 \mathrm{ft}$ below sea level), screened in the lower layer in the northwestern part of the subregional model area, was $15 \mathrm{ft}$ higher than the measured water level, apparently indicating effects of processes not accounted for in the simulation. Simulation results in all other modeled areas, including Stone Harbor, were acceptable. 


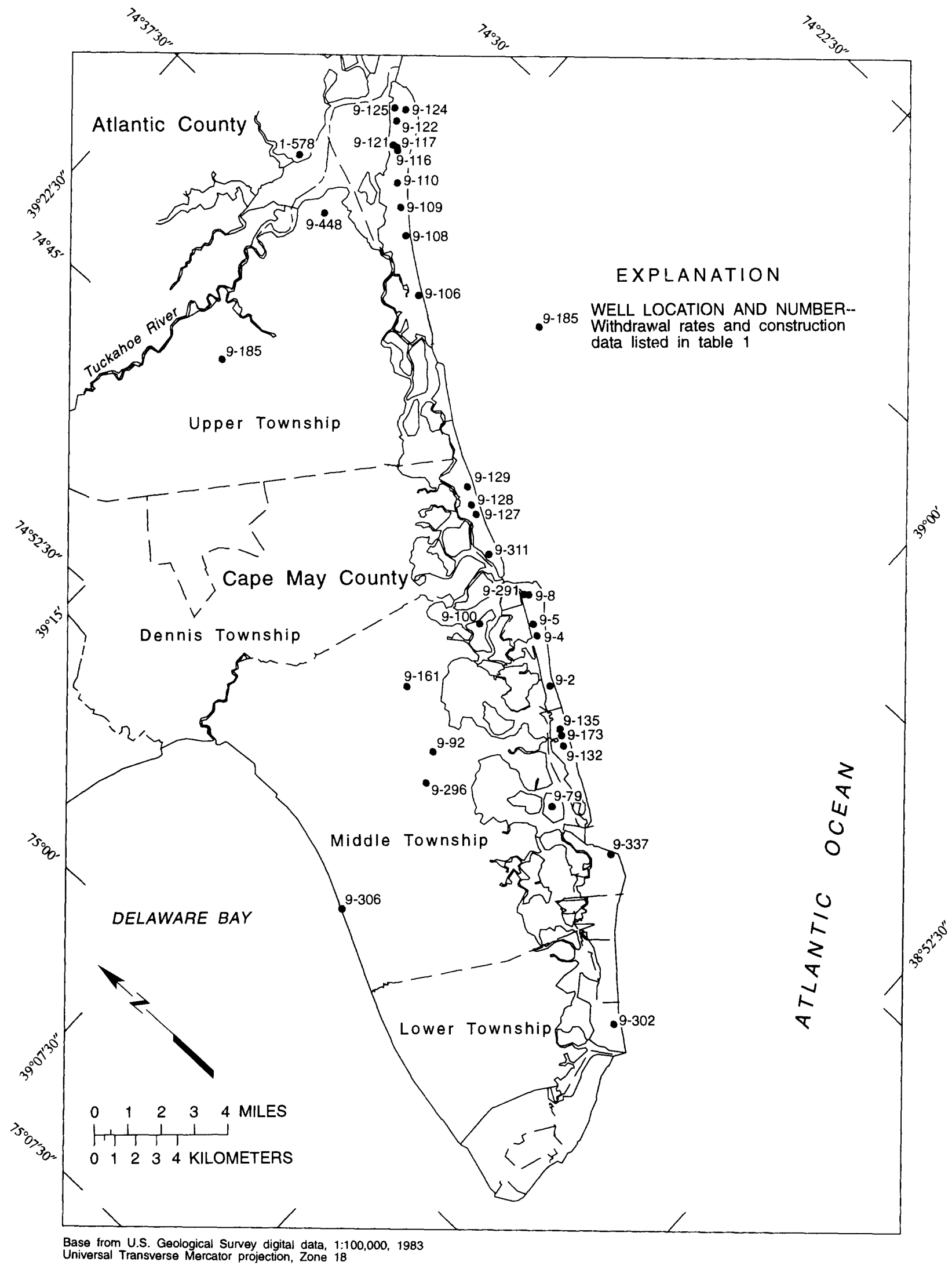

Figure 6. Location of selected industrial, public supply, and observation wells screened in the Atlantic City 800-foot sand in Cape May and Atlantic Counties, New Jersey. 
Table 2. Well-construction data and average annual withdrawals during 1983-88 for selected wells in Cape May and Atlantic Counties, New Jersey

[Withdrawals in million gallons per year; NJDEP, New Jersey Department of Environmental Protection; N/A, not available; USGS, U.S.Geological Survey]

\begin{tabular}{|c|c|c|c|c|c|}
\hline $\begin{array}{c}\text { USGS } \\
\text { well number }\end{array}$ & $\begin{array}{l}\text { NJDEP } \\
\text { well-permit } \\
\text { number }\end{array}$ & Local well name & $\begin{array}{c}\text { Depth of } \\
\text { well } \\
\text { (feet below } \\
\text { land surface) }\end{array}$ & $\begin{array}{c}\text { Screened } \\
\text { interval } \\
\text { (feet below land } \\
\text { surface) }\end{array}$ & $\begin{array}{c}\text { Average annual } \\
\text { ground-water } \\
\text { withdrawals, } \\
1983-88\end{array}$ \\
\hline $1-578$ & $\mathrm{~N} / \mathrm{A}$ & JOBS POINT OBS & 680 & $670-680$ & 0 \\
\hline $9-2$ & $37-00280$ & AVALON WD 7-71 & 861 & $821-861$ & 81.7 \\
\hline $9-4$ & $37-00265$ & AVALON WD 6 & 920 & $880-920$ & 106.1 \\
\hline $9-5$ & $37-00313$ & AVALON WD 8-76 & 839 & $784-839$ & 105.4 \\
\hline $9-8$ & N/A & AVALON WD 3 & 925 & $845-925$ & 31.6 \\
\hline $9-79$ & N/A & TEST HOLE 2 & 876 & $833-876$ & 0 \\
\hline 9. 92 & $37-00240$ & NEPTUNUS 7 & 791 & $681-791$ & 117.9 \\
\hline $9-100$ & $37-00224$ & AVALON M WW 1 & 827 & $763-815$ & 7.3 \\
\hline 9.106 & $56-00006$ & SHORE DIV 7 & 810 & $760-810$ & 113.5 \\
\hline $9-108$ & $36-00413$ & SHORE DIV 14 & 840 & $774-840$ & 113.5 \\
\hline $9-109$ & $56-00008$ & SHORE DIV 9 & 809 & $749-809$ & 113.5 \\
\hline $9-110$ & $36-00373$ & SHORE DIV 12 & 814 & $\mathrm{~N} / \mathrm{A}$ & 113.5 \\
\hline $9-116$ & $56-00007$ & SHORE DIV 8 & 810 & N/A & 113.5 \\
\hline $9-117$ & $36-00117$ & SHORE DIV 10 & 798 & $746-798$ & 113.5 \\
\hline $9-121$ & N/A & SHORE DIV 4 & 825 & N/A & $\mathbf{0}$ \\
\hline $9-122$ & $56-00005$ & SHORE DIV 5 & 825 & N/A & 113.5 \\
\hline $9-123$ & N/A & 2 & 795 & $745-795$ & 113.5 \\
\hline $9-124$ & $36-00412$ & SHORE DIV 13 & 846 & $757-840$ & 113.5 \\
\hline $9-125$ & $36-00314$ & SHORE DIV 11 & 800 & $\mathrm{~N} / \mathrm{A}$ & 113.5 \\
\hline $9-126$ & $37-00162$ & SICWD 5 & 802 & $731-802$ & 122.4 \\
\hline $9-127$ & $37-00064$ & SICWD 4 & 830 & $742-830$ & 97.9 \\
\hline $9-128$ & $57-00010$ & SICWD 3 & 870 & $800-870$ & 87.1 \\
\hline $9-129$ & $57-00009$ & SICWD 2 & 861 & $744-861$ & 116.2 \\
\hline $9-132$ & $37-00079$ & SHWD 4 & 880 & $830-880$ & 51.5 \\
\hline $9-135$ & $37-00009$ & SHWD 3 & 878 & $837-877$ & 51.5 \\
\hline $9-136$ & $\mathrm{~N} / \mathrm{A}$ & CIWC 1 & 834 & $802-834$ & 49.7 \\
\hline $9-148$ & $36-00364$ & ACEC 3 Layne 4 & 675 & $645-680$ & 66.8 \\
\hline $9-161$ & N/A & 1 & 654 & $639-654$ & N/A \\
\hline $9-166$ & $37-00312$ & SHWD 5 & 860 & $820-860$ & 51.5 \\
\hline $9-173$ & $37-00579$ & SHWD 6 & 862 & $822-862$ & 51.8 \\
\hline $9-185$ & N/A & MACNAMARA W A & 650 & $640-650$ & $\mathrm{~N} / \mathrm{A}$ \\
\hline $9-291$ & $36-09846$ & AVALON WD 9 & 946 & $764-941$ & 37.0 \\
\hline $9-296$ & $35-06073$ & HAND AVE 8 & 817 & $682-812$ & $\mathrm{~N} / \mathrm{A}$ \\
\hline $9-302$ & $37-03628-9$ & COAST GUARD 800 & 903 & $883-893$ & $\mathrm{~N} / \mathrm{A}$ \\
\hline $9-306$ & $\mathrm{~N} / \mathrm{A}$ & OYSTER 800 & 709 & $656-666$ & N/A \\
\hline $9-311$ & $36-10378$ & SICWD 6-1989 & 901 & $732-896$ & N/A \\
\hline $9-337$ & $37-04660$ & M-1 N WILDWOOD 800 & 965 & $910-960$ & $\mathrm{~N} / \mathrm{A}$ \\
\hline
\end{tabular}



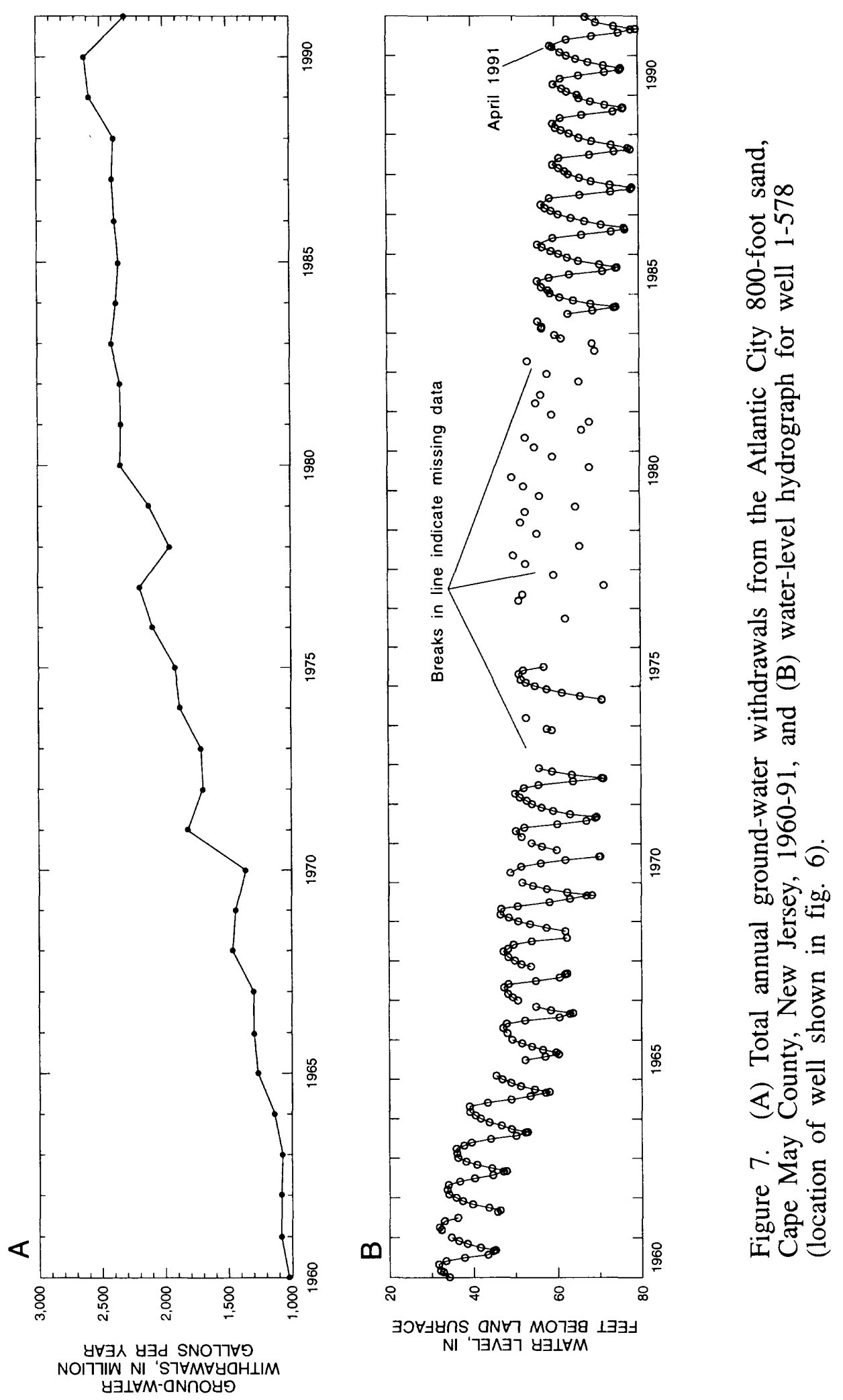


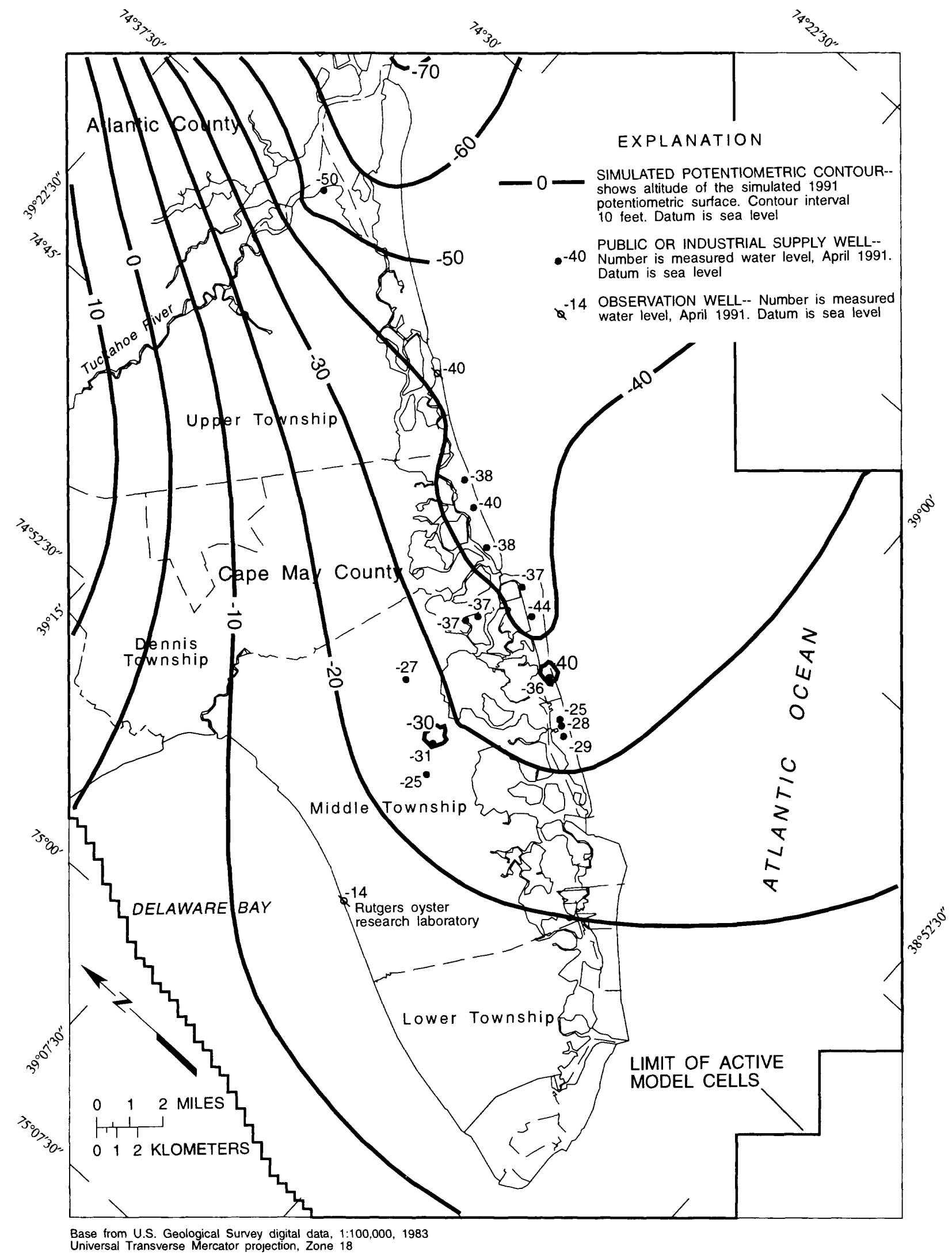

Figure 8. Simulated potentiometric surface and measured water levels in the upper layer of the Atlantic City 800-foot sand, Cape May County, New Jersey, 1991. 


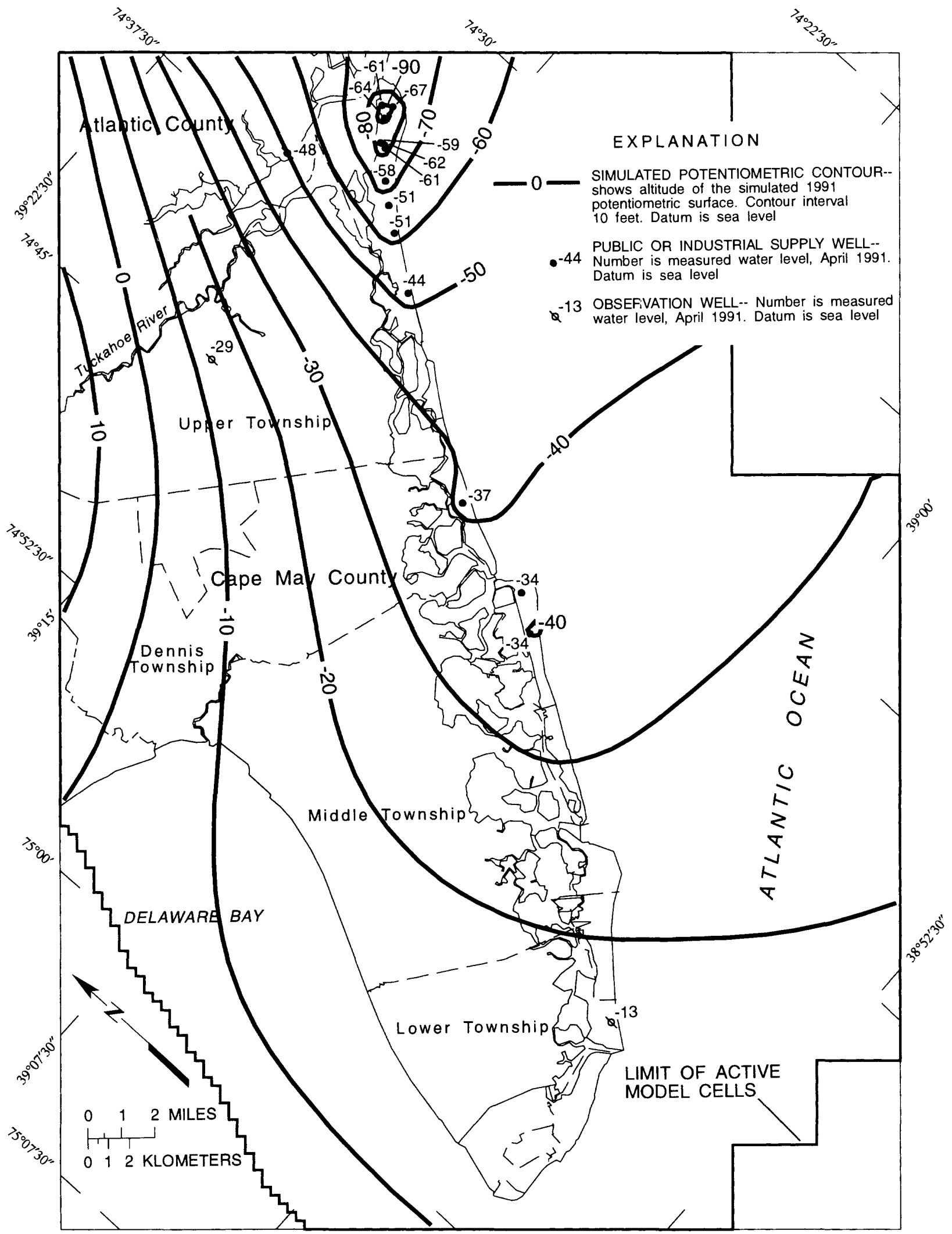

Base from U.S. Geological Survey digital data, 1:100,000, 1983 Universal Transverse Mercator projection, Zone 18

Figure 9. Simulated potentiometric surface and measured water levels in the lower layer of the Atlantic City 800-foot sand, Cape May County, New Jersey, 1991. 
The previously defined limit of the confining unit overlying the Atlantic City 800foot sand in the Delaware Bay (D.A. Pope, U.S. Geological Survey, written commun., 1991) was refined to achieve a good match between measured and simulated water levels for the well at the Rutgers oyster research laboratory (9-306, fig. 8). Therefore, the limit of the overlying confining unit in this area in the subregional model was slightly west of the limit used in the regional model (fig. 1).

\section{SALTWATER INTRUSION AND TRAVEL TIME}

\section{Saltwater Intrusion}

The inferred location of the $250-\mathrm{mg} / \mathrm{L}$ line of equal chloride concentration in ground water in the Atlantic City 800-foot sand in 1992 (P.J. Lacombe and G.B. Carleton, U.S. Geological Survey, written commun., 1992) is shown in figure 10. The location is based on results of laboratory analyses of water samples collected from observation wells drilled in 1988 and 1992 and the most recent (dates given in fig. 10) chemical analyses of samples from public and industrial supply wells that are abandoned or in use in Cape May County. The line bends toward the mainland as it crosses the peninsula and bends toward the edge of the overlying confining unit to account for the likelihood that saltwater flows from the Delaware Bay toward the supply wells in Cape May County. This orientation is supported, in part, by the concentration of chloride in a sample collected from the observation well at the Rutgers research oyster laboratory (fig. 10). The chloride concentration, $49 \mathrm{mg} / \mathrm{L}$, was higher than background concentrations, which ranged from 10 to $36 \mathrm{mg} / \mathrm{L}$ in water samples from wells on or near the barrier islands in Cape May County. The location of the $250-\mathrm{mg} / \mathrm{L}$ line of equal chloride concentration in the offshore area is based on data from four wells--two offshore near Atlantic City, one at North Wildwood, and one at the U.S. Coast Guard base electronic station (fig. 10).

Flows at model boundaries under average 1983-88 ground-water withdrawal conditions provide an indication of the relative importance of sources of water to the Atlantic City 800-foot sand (table 3; fig. 10). The most significant flow into the study area $(7.52 \mathrm{ft} / \mathrm{s})$ is freshwater recharge from the area where the confining unit that overlies the Atlantic City 800- foot sand is absent (boundary 2). This flow represents 59 percent of the total ground-water flow into the subregional model area. About 22 percent $(2.74 \mathrm{ft} / \mathrm{s})$ of the total ground-water flow into the area is saltwater that flows across boundary 4 . Vertical flow from the aquifers above and below the Atlantic City 800 -foot sand accounts for 14 percent $(1.78 \mathrm{ft} / \mathrm{s})$ of ground-water flow into the model area. Flow from the Delaware Bay (boundary 1) is saltwater that accounts for about 5 percent $(0.60 \mathrm{ft} / \mathrm{s})$ of the ground water entering the model area. 


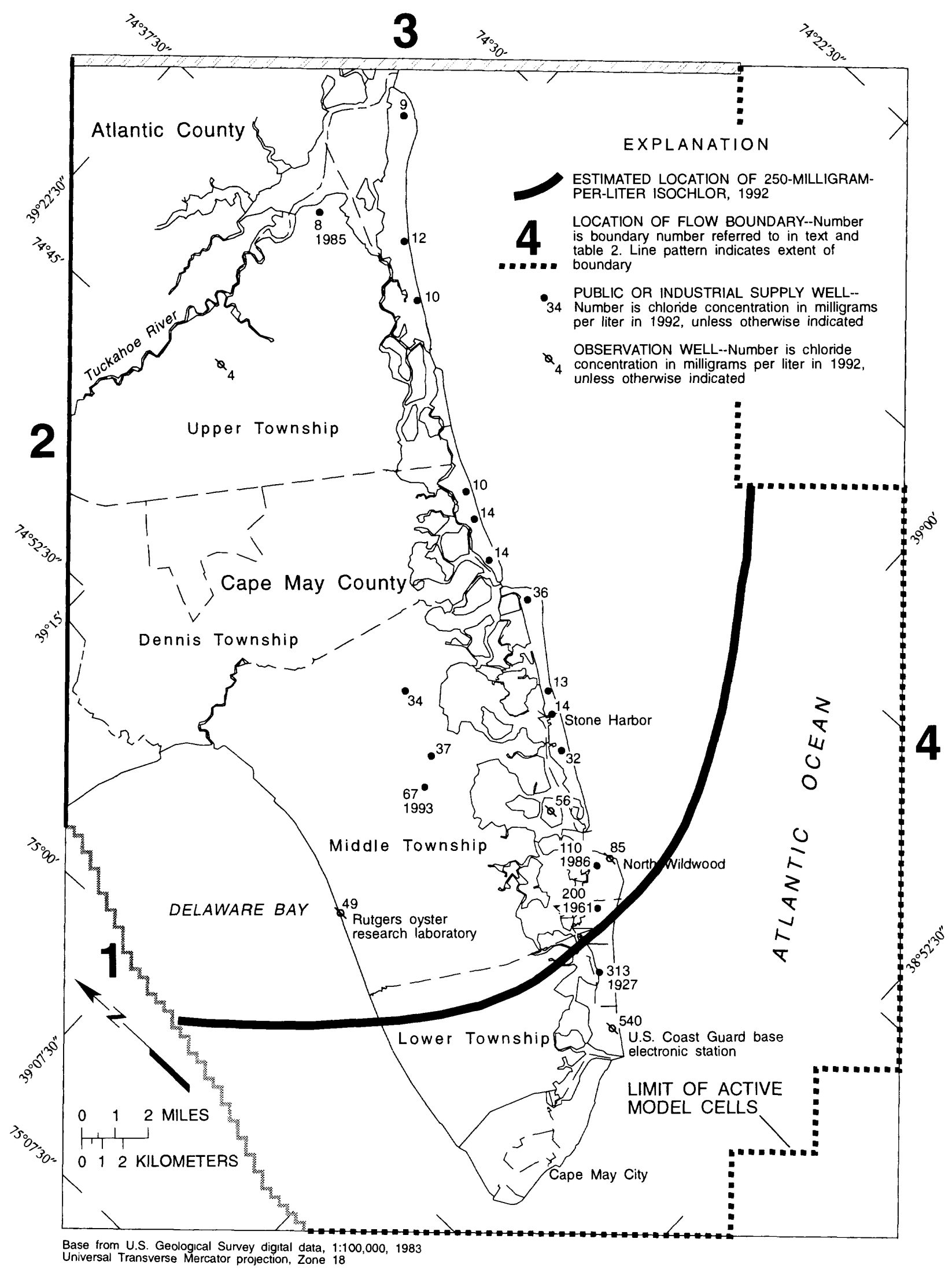

Figure 10. Estimated location of areas where chloride concentrations exceed 250 milligrams per liter in the Atlantic City 800-foot sand, Cape May County, New Jersey, 1992. (From P.J. Lacombe and G.B. Carleton, U.S. Geological Survey, written commun., 1992) 
Table 3. Simulated 1983-88 steady-state ground-water budget of the Atlantic City 800-foot sand, Cape May County, New Jersey

[Rates in cubic feet per second; boundary locations are shown in figure 10]

\begin{tabular}{lcc}
\hline & Inflow & Outflow \\
\hline Boundary & & \\
$\quad$ Lateral flow & & \\
$\quad$ Boundary 1 & 0.60 & 0.00 \\
Boundary 2 & 7.52 & .00 \\
Boundary 3 & .00 & 2.55 \\
Boundary 4 & 2.74 & .00 \\
Vertical flow through & 1.46 & .05 \\
$\quad$ upper confining unit & & .01 \\
Vertical flow through & .32 & 10.03 \\
lower confining unit & & 12.64 \\
Pumpage & .00 & \\
Total & 12.64 & \\
\hline
\end{tabular}


Beneath the barrier islands, chloride concentrations in ground water in the Kirkwood-Cohansey aquifer system, which overlies the Rio Grande water- bearing zone and Atlantic City 800-foot sand, exceed $250 \mathrm{mg} / \mathrm{L}$ (Spitz and Barringer, 1992). Ground water in the underlying Piney Point aquifer contains chloride in concentrations that exceed $250 \mathrm{mg} / \mathrm{L}$ throughout most of Cape May County. These aquifers could be a minor source of saltwater to the Atlantic City 800 -foot sand in the model area. Predevelopment water levels (Zapecza and others, 1987) in the Atlantic City 800-foot sand in the Stone Harbor area were higher than those in the overlying Kirkwood-Cohansey aquifer system and the underlying Piney Point aquifer; therefore, fresh ground water from the Atlantic City 800foot sand would have flowed vertically into these aquifers. The overlying and underlying confining units probably contain freshwater rather than saltwater because of these flows from the Atlantic City 800-foot sand. Results of the simulation in which vertical specified fluxes were $0.0001258 \mathrm{ft} / \mathrm{s}$ (calculated from the regional model in the Stone Harbor area), estimated porosity was 0.35 , and confining-unit thickness was $150 \mathrm{ft}$ indicate that thousands of years would be required for saltwater to flow through the thick confining units to the Atlantic City 800-foot sand if withdrawals are maintained at 1991 levels.

\section{Travel Time}

A particle-tracking post-processor was used to compute three-dimensional flow paths from areas where chloride concentrations exceed $250 \mathrm{mg} / \mathrm{L}$ to public supply wells at Stone Harbor, New Jersey. The positions of these flow paths, which were determined on the basis of 1991 ground-water withdrawals, are shown in figure 11. All travel times shown are for lateral flow. Actual travel times may differ from predicted travel times as a result of the uncertainty in estimating the location of the $250-\mathrm{mg} / \mathrm{L}$ line of equal chloride concentration.

Results of particle-tracking analysis indicate that the time required for saltwater to reach the public supply wells at Stone Harbor if ground-water withdrawals are maintained at 1991 rates is on the order of hundreds of years. However, these results are based on the assumptions that the aquifer is homogeneous and that the horizontal hydraulic conductivities of both layers of the Atlantic City 800-foot sand in Cape May County are identical. The presence of zones of high permeability in the aquifer could reduce the predicted travel time of the saltwater from its present location to the wells at Stone Harbor. In addition, the accuracy of predicted travel times is limited by the uncertainties inherent in the representation of the natural hydrologic conditions and the possibility that the rate of ground- water withdrawals will increase. Therefore, travel times could be shorter than those predicted. 


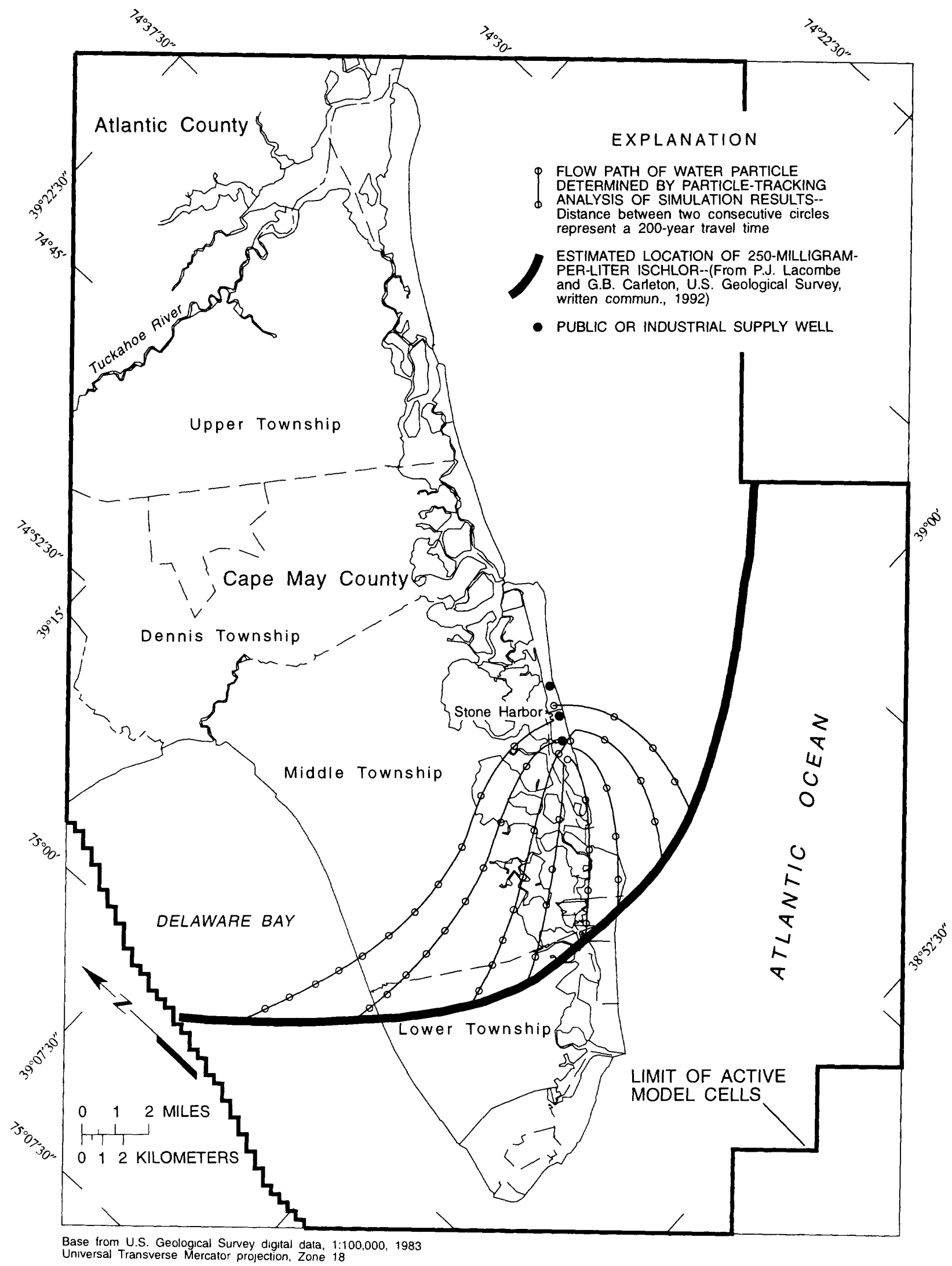

Figure 11. Flow paths of water particles in the upper layer of the Atlantic City 800-foot sand, Cape May County, New Jersey, determined by particle-tracking analysis of simulation results, 1991. 


\section{SUMMARY AND CONCLUSIONS}

Ground water is the most important source of public water supply in Cape May County, New Jersey. In the barrier-island communities, ground water is withdrawn from the regionally confined aquifer system, the Atlantic City 800-foot sand. The presence of saline ground water (ground water in which the chloride concentration exceeds $250 \mathrm{mg} / \mathrm{L}$ ) in Cape May County was documented in 1926 when water samples from a well screened in the Atlantic City 800-foot sand in Wildwood were found to contain chloride in a concentration of $352 \mathrm{mg} / \mathrm{L}$. Increasing evidence of the landward movement of saltwater in other aquifers led to concern about the future adequacy of freshwater supplies from the Atlantic City 800-foot sand in Cape May County. Therefore, the U.S. Geological Survey, in cooperation with the New Jersey Department of Environmental Protection, undertook a study of saltwater intrusion in this aquifer in order to estimate the travel time of the saltwater from its present location to the county's nearest public supply wells.

A regional and a subregional ground-water-flow model were coupled to assess the effects of ground-water withdrawals on the movement of saltwater in the Atlantic City 800 -foot sand. First, a regional model of ground- water flow through the sediments of the New Jersey Coastal Plain was used to estimate the quantity and distribution of flow across the natural and artificial boundaries of the Cape May subregional model area. Next, the results of this simulation were input to the subregional model to refine the estimates of flow in the Atlantic City 800-foot sand in the smaller area of interest. Finally, a particletracking method was used to determine ground-water-flow paths and travel time from parts of the aquifer that contain saltwater to the public supply wells at Stone Harbor, New Jersey.

Results of the analysis indicate that the time required for saltwater to reach the public supply wells is on the order of hundreds of years. These results, however, are based on the assumptions that the aquifer is homogeneous, and that ground-water withdrawals are maintained at 1991 rates. The presence of zones of high permeability in the aquifer or an increase in ground-water withdrawals could reduce the predicted travel times of the saltwater from its present location to the supply wells. 


\section{REFERENCES CITED}

Bauersfeld, W.R., Moshinsky, E.W., Pustay, E.A., and Jones, W.D., 1990, Water resources data, New Jersey, Water year 1989: U.S. Geological Survey Water-Data Reports $\mathrm{NJ}-89-1$ and $\mathrm{NJ}-89-2$, various pagination.

Buxton, H.T., and Reilly, T.E., 1987, A technique for analysis of ground-water systems at regional and subregional scales applied on Long Island, New York, in Subitzky, Seymour, ed., Selected papers in the hydrologic sciences, 1986: U.S. Geological Survey Water-Supply Paper 2310, p. 129-142.

Eckel, J.A., and Walker, R.L., 1986, Water levels in major artesian aquifers of the New Jersey Coastal Plain, 1983: U.S. Geological Survey Water-Resources Investigations Report 86-4028, 62 p.

Essaid, H.I., 1990, The computer model SHARP, a quasi-three-dimensional finitedifference model to simulate freshwater and saltwater flow in layered coastal aquifer systems: U.S. Geological Survey Water-Resources Investigations Report 90-4130, $181 \mathrm{p}$.

Geraghty and Miller, Inc., 1971, Ground water resources in Cape May County, 1970: Port Washington, N.Y., $90 \mathrm{p}$.

Gill, H.E., 1962a, Ground-water resources of Cape May County, N.J.--Saltwater invasion of principal aquifers: New Jersey Department of Conservation and Economic Development, Special Report 18, 171 p.

$1962 b$, Records of wells, well logs, and summary of stratigraphy of Cape May

County, New Jersey: New Jersey Department of Conservation and Economic Development, Division of Water Policy and Supply, Circular 8, 54 p.

Leahy, P.P., and Martin, Mary, 1993, Geohydrology and simulation of ground-water flow in the northern Atlantic Coastal Plain aquifer system: U.S. Geological Survey Professional Paper 1404-K, 81 p.

Martin, Mary, in press, Ground-water flow in the New Jersey Coastal Plain aquifers: U.S.Geological Survey Professional Paper 1404-H.

McDonald, M.G., and Harbaugh, A.W., 1988, A modular three- dimensional finitedifference ground-water flow model: U.S. Geological Survey Open-File Report $83-875,528 \mathrm{p}$. 


\section{REFERENCES CITED--Continued}

Meisler, Harold, 1980, Preliminary delineation of salty ground water in the northern Atlantic Coastal Plain: U.S. Geological Survey Open-File Report 81-71, 37 p.

Meisler, Harold, Leahy, P.P., and Knobel, L.L., 1985, Effect of eustatic sea-level changes on saltwater-freshwater relations in the northern Atlantic Coastal Plain: U.S. Geological Survey Water-Supply Paper 2255, 28 p.

Pollock, D.W., 1989, Documentation of computer programs to compute and display pathlines using results from the U.S. Geological Survey modular three-dimensional finite- difference ground-water flow model: U.S. Geological Survey Open-File Report 89-381, $188 \mathrm{p}$.

Rosman, R., Lacombe P.J., and Storck, D.A., 1996, Water levels in the major aquifers of the New Jersey Coastal Plain, 1988: U.S. Geological Survey Open-File Report 95-4060.

Schaefer, F.L., 1983, Distribution of chloride concentrations in the principal aquifers of the New Jersey Coastal Plain, 1977-81: U.S. Geological Survey Water-Resources Investigations Report 83-4061, $56 \mathrm{p}$.

Seaber, P.R., 1963, Chloride concentrations of water from wells in the Atlantic Coastal Plain of New Jersey, 1923-61: New Jersey Department of Conservation and Economic Development, Division of Water Policy and Supply, Special Report 22, $250 \mathrm{p}$.

Spitz, F.J., and Barringer, T.B., 1992, Ground-water hydrology and simulation of saltwater encroachment, shallow aquifer system of southern Cape May County, New Jersey: U.S. Geological Survey Water-Resources Investigations Report 91-4191, 87 p.

Vowinkel, E.F., 1984, Ground-water withdrawals from the Coastal Plain of New Jersey, 1956-1980: U.S. Geological Survey Open-File Report 84-226, 32 p.

Vowinkel, E.F., and Foster, W.K., 1981 Hydrogeologic conditions in the Coastal Plain of New Jersey: U.S. Geological Survey Open-File Report 81-405, 39 p.

Walker, R., 1983, Evaluation of water levels in major aquifers of the New Jersey Coastal Plain, 1978: U.S. Geological Survey Water- Resources Investigations Report $87-4038,120 \mathrm{p}$.

Zapecza, O.S., 1989, Hydrogeologic framework of the New Jersey Coastal Plain: U.S. Geological Survey Professional Paper 1404-B, 49 p., 24 pl. 


\section{REFERENCES CITED--Continued}

Zapecza, O.S., Voronin, L.M., and Martin, Mary, 1987, Ground- water-withdrawal and water-level data used to simulate regional flow in the major Coastal Plain aquifers of New Jersey: U.S. Geological Survey Water-Resources Investigations Report $87-4038,120 \mathrm{p}$. 